She, as well as the Samoan chiefs and the natives, showed us every possible courtesy and hospitability and evinced great interest in the success of our work. The party was entertained by the "village fathers" at a native feast and Vaitupu gave a siwa in our honor.

Thursday, the day before the eclipse, unfortunately, was cloudy and showery and our preparations were greatly retarded in consequence. As my chief object was to ascertain whether there might be any possible magnetic effect during the eclipse, I had to pay prime attention to the magnetic observations and to the training of an assistant, Quartermaster Urle, of the Annapolis, for taking readings of the magnetic declination every minute for about five hours on the day of the eclipse.

I was fortunate in being able to turn the charge of the photographic work over to Lieut. McDowell, U. S. N., in command of the Annapolis; he was assisted by Messrs. Reed and Steffany, also by Dr. Connor and Chaplain Pierce-all of the Annapolis. I made the necessary calculations for the orientation of the camera and laid out the necessary lines for guidance in the placing of the camera. Owing to the inclement weather the day before, it was not possible to get the camera finally mounted and in proper position until shortly before totality. The day of eclipse was fortunately clear throughout. There was no opportunity for trying out the finding telescope and slow motion screws in declination and right ascension.

Just before totality, Lieut. McDowell found that he could not use the finder and so rigged up a hastily constructed sighting device for keeping the sun's image centered on the plates and eliminating the diurnal motion. Two exposures of 15 seconds and two of $1 \mathrm{~m}$. $10 \mathrm{~s}$. were obtained. When the plates were developed, it was found that the improvised sighting device had not been wholly successful and so the photographs exhibit effects due to diurnal motion. Apart, however, from these defects, the photographs show clearly not only the inner corona but also most interesting details and coronal extensions reach- ing out over one half of the sun's diameter. The present corona thus fulfilled the expectations of great development during a sun-spot minimum.

The mean duration of totality, as observed at shore by Lieut. McDowell and Dr. Connor, and aboard the Annapolis by Lieut. Baker, U. S. N., was $2 \mathrm{~m} .1 \mathrm{~s}$. The great coronal extensions which were chiefly in the sun's southwestern and northeastern edges were not seen visually, for some reason, by any member of the shore party nor by the party aboard the Annapolis anchored a few miles distant, in Faleasau Bay. They were, however, seen by two observers to my knowledge, in the Tongas, viz., Capt. Holford on board the Tofua and by Mrs. Clement Wragge, who with her husband, the well-known meteorologist, was located near Hapaii, Id.

It is greatly to be regretted that the better equipped and specially trained astronomical parties at Vavau, Tonga, were not blessed with the singular good fortune which befell us at Tau Island. For our prime work-magnetic-it would not have mattered had the weather been bad.

According to special arrangement magnetic observations simultaneous with ours at Tau were made at the five coast and geodetic survey magnetic observatories, also at Melbourne, Christchurch and Apia, where quickrun magnetograms were obtained for five hours. Until the records have been received from stations over the entire globe, it will not be possible to determine definitely whether or not the present eclipse was accompanied by any minute and temporary change in the earth's magnetism.

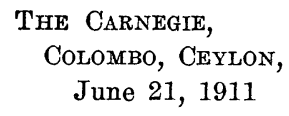

\section{SAMUEL CALVIN}

Some weeks ago there appeared in ScIENCE a brief notice of the death, on April 17, of Professor Samuel Calvin, head of the department of geology in the University of Iowa, and state geologist of Iowa. 
Samuel Calvin was born in Wigtonshire, Scotland, February 2, 1840. He came with his parents to America when he was eleven years of age. For three years the family lived on a farm in the state of New York, then they came to Iowa, where from that time until his death Samuel Calvin made his home.

He received his college education at Lenox College, Ia. When he was twenty-four years old he enlisted in the army and served for a few months in the civil war. After returning from the war, he was for four years a teacher of science in Lenox College. He resigned this position to go to Dubuque, where, for seven years, he was principal of a ward school. In 1874 he was elected to a professorship of natural science in the University of Iowa. Here, at first, he had charge of botany, zoology, geology and physiology. Later, he was made professor of geology, a position which he filled with distinction until his death.

He received from Cornell College the degrees of M.A. and LL.D., and from Lenox College the degree of Ph.D.

In the year 1865 he married Louise Jackson, of Hopkinton, Ia. She, a son and a daughter survive him.

In the year 1892 Dr. Calvin was elected state geologist of Iowa. This position he resigned in 1904 owing to the stress of other duties. However, in 1906, upon the resignation of Professor Wilder, he was again elected state geologist and continued to serve until his death. The Iowa Geological Survey under his directorship published about twenty volumes of reports dealing with the geology and mineral resources of the state. Of great scientific value have been his own contributions to the geology of Iowa, especially those papers which have added to our knowledge of the Pleistocene. His most recent scientific publications, which deal with the Aftonian mammalian fauna have done much to unravel some of the difficult problems of Pleistocene paleontology. In all his scientific work he was thorough, no details were considered trivial-his one desire was to discover truth-to find any facts which could make knowledge clearer, broader, more definite. That he had the power to clothe his thoughts in beautiful language is clearly shown in all his writings.

Professor Calvin was a great teacher and his students loved him. His simplicity, his gentleness, his love of justice and truth, his intolerance of deceit and sham, his deep sympathy, his high regard for religion, his lofty ideals of life-these were the characteristics by which he influenced the lives of those who had the privilege of knowing him. Only such a man as he could have given expression to the following tribute to noble manhood:

Wherever noble deeds are done for truth and right; wherever weak, despairing, fainting, faltering men and women need encouragement to take up heroically the burdens and duties of life; wherever sorrow yearns for sympathy and consolation, or sickness creates necessity for tender ministrations, where the pestilence walketh in darkness; where sin, foul and loathsome, waits for victims; where overpowering temptation saps the foundations of the better will and weaves inextricable toils; wherever, indeed, many-sided humanity calls for help, there will you find some messenger of truth, forgetting self, filled with zeal for God and fellowmen, lifting, helping, encouraging, consoling; pointing out the path of wisdom and the path of peace; illustrating the importance of right living, and leading all to the true appreciation of the beauty of holiness. Such is the noble side of human nature, such is the grand side.

In the death of Samuel Calvin the nation has lost a distinguished scholar, an inspiring teacher and a true and noble man.

State UnIVERsity of Iowa

George F. KaY

\section{SCIENTIFIC NOTES AND NEWS}

Professor W. Johannsen, of the University of Copenhagen, whose recent work on heredity and pure lines has attracted much attention, is to give in October and November a course of lectures and seminar conferences on "Modern Conceptions of Heredity" at Columbia University, under the joint auspices of the departments of botany and zoology. Four public lectures will be given on the afternoons of October 13, 20, 27 and November 3, and 